\title{
Change of connexin 37 in allergen-induced airway inflammation
}

\author{
Seoung Ju Park* ${ }^{1 *}$ Kyung Sun Lee ${ }^{1 *}$, So Ri Kim, \\ Kyung Hoon Min ${ }^{1}$, Ka Young Lee, \\ Yeong Hun Choe', Seung Yong Park', \\ Sang Hyun Hong ${ }^{1}$ and Yong Chul Lee ${ }^{1,2}$ \\ ${ }^{1}$ Department of Internal Medicine and Airway Remodeling Laboratory \\ Chonbuk National University Medical School \\ Jeonju 561-180, Korea \\ ${ }^{2}$ Corresponding author: Tel, 82-63-250-1664; \\ Fax, 82-63-254-1609; E-mail, leeyc@ chonbuk.ac.kr \\ ${ }^{\star}$ These authors contributed equally to this work.
}

Accepted 14 August 2007

Abbreviations: BAL, bronchoalveolar lavage; $\mathrm{Cx}$, connexin; ICAM-1, intercellular adhesion molecule-1; OVA, ovalbumin; $\mathrm{R}_{\mathrm{L}}$, airway resistance; VCAM-1, vascular cell adhesion molecule-1

\begin{abstract}
Gap junction channels formed with connexins directly link to the cytoplasm of adjacent cells and have been implicated in intercellular signaling. Connexin 37 (Cx37) is expressed in the gas-exchange region of the lung. Recently, Cx37 has been reported to be involved in the pathogenesis of inflammatory disease. However, no data are available on the role of $\mathrm{Cx} 37$ in allergic airway inflammatory disease. In the present study, we used a murine model of ovalbumin (OVA)induced allergic airway disease and primary murine epithelial cells to examine the change of $\mathrm{C} \times 37$ in allergic airway disease. These mice develop the following typical pathophysiological features of asthma: airway hyperresponsiveness, airway inflammation, and increased IL-4, IL-5, IL-13, intercellular adhesion molecule-1, vascular cell adhesion molecule-1, eotaxin, and RANTES levels in lungs. Cx37 protein and mRNA expression were decreased in OVA-induced allergic airway disease. Immunoreactive $\mathrm{Cx} 37$ localized in epithelial layers around the bronchioles in control mice, which dramatically disappeared in allergen-induced asthmatic lungs. Moreover, the levels of $\mathrm{Cx} 37$ protein in lung tissues showed significantly negative correlations with airway inflammation, airway responsiveness, and levels of Th2 cytokines in lungs. These findings indicate that change of $\mathrm{C} \times 37$ may be associated with the asthma phenotype.
\end{abstract}

Keywords: asthma; connexin 37; epithelial cells; gap junctions; inflammation mediators; models, animal; respiratory system

\section{Introduction}

Connexins (Cxs), connexons, and gap junctions are involved in numerous processes contributing to the maintenance of normal cell growth and differentiation (Saez et al., 2003; Jiang and Gu, 2005). The gap junction channels formed with Cxs directly link to the cytoplasm of adjacent cells and have been implicated in intercellular signaling that may regulate the functions of cells. The gap junction channels allow intercellular passage of ions, second messengers (such as $\mathrm{Ca}^{2+}, \mathrm{IP}_{3}, \mathrm{CAMP}$, and cGMP), and small metabolites. Cxs are members of a family of proteins encoded by at least 20 different mammalian genes that are expressed in a wide variety of tissues (Saez et al., 2003; Sohl and Willecke, 2004). Previous studies have shown that at least eight Cxs are expressed in the gasexchange region of the lung; these include $\mathrm{Cx} 26$, Cx30.3, Cx32, Cx37, Cx40, Cx43, Cx45, and Cx46 (Paul, 1995; Lee et al., 1997; Abraham et al., 1999). Recently, Cx37 has been reported to play a role in the pathogenesis of various inflammatory diseases (Wagenaar et al., 2004; Chanson and Kwak, 2007). Moreover, proinflammatory cytokines are shown to reduce expression of $\mathrm{C} \times 37$, resulting in a decrease in gap junction-mediated communication (van Rijen et al., 1998). Asthma is a chronic inflammatory disease of the airways in which many cell types play a role, in particular mast cells, eosinophils, T lymphocytes, and airway epithelial cells (National Institutes of Health, 1995; Lilly et al., 2005). In susceptible individuals, the inflammation causes recurrent episodes of wheezing, breathlessness, chest tightness, and cough particularly at night and/or early morning. These symptoms are usually associated with widespread but variable airflow obstruction that is at least partly reversible either spontaneously or with treatment. The inflammation also causes an associated increase in airway responsiveness to a variety of stimuli. However, no data are available on the role of $\mathrm{Cx} 37$ in pathogenesis of allergic airway inflammatory disease and the precise localization of $\mathrm{C} \times 37$ has not been fully determined in lungs. 
In the present study, we used ovalbumin (OVA)inhaled mice to examine the change of $\mathrm{C} \times 37$ in allergic airway disease, and we also evaluated whether Cx37 is expressed in airway epithelial cells.

\section{Materials and Methods}

\section{Animals and experimental protocol}

Female C57BL/6 mice, 8 to 10 wk of age and free of murine specific pathogens, were obtained from the Orientbio Inc. (Seoungnam, Korea), were housed throughout the experiments in a laminar flow cabinet, and were maintained on standard laboratory chow ad libitum. All experimental animals used in this study were under a protocol approved by the Institutional Animal Care and Use Committee of the Chonbuk National University Medical School. Standard guidelines for laboratory animal care were followed (Institute of Laboratory Animal Research, 1996). Mice (8 mice per group) were sensitized on days 1 and 14 by i.p. injection of $20 \mu \mathrm{g}$ OVA (Sigma-Aldrich, St. Louis, MO) emulsified in $1 \mathrm{mg}$ of aluminum hydroxide (Pierce Chemical Co., Rockford, IL) in a total volume of $200 \mu \mathrm{l}$, as previously described with some modifications (Kwak et al., 2003; Lee et al., 2006a, b). On days 21,22 , and 23 after the initial sensitization, the mice were challenged for $30 \mathrm{~min}$ with an aerosol of $3 \%(\mathrm{wt} / \mathrm{vol})$ OVA in saline (or with saline) using an ultrasonic nebulizer (NE-U12, Omron, Japan). Bronchoalveolar lavage (BAL) was performed at indicated time after the last challenge. Total cell numbers were counted with a hemocytometer. Smears of BAL cells were prepared with a cytospin (Thermo Electron, Waltham, MA). The smears were stained with Diff-Quik solution (Dade Diagnostics of P. R. Inc. Aguada, Puerto Rico) in order to examine the cell differentials.

\section{Isolation and primary culture of murine tracheal epithelial cells}

Murine tracheal epithelial cells were isolated from 5 independent mice under sterile conditions, as previously described (Kwak et al., 2003). The trachea proximal to the bronchial bifurcation was excised and adherent adipose tissue was removed. The trachea was opened longitudinally and cut into three pieces. The isolated tracheas were incubated in DMEM containing $0.1 \%$ protease overnight at $4^{\circ} \mathrm{C}$. Following tissue digestion, FBS $(10 \%$ final concentration) was added to the medium to deactivate enzymes, undigested fragments of tissue were removed, and tracheal epithelial cells were harvested by centrifugation at $100 \times g$ for $5 \mathrm{~min}$. The epithelial cells were seeded onto 35-mm collagen-coated dishes for submerged culture. The growth medium DMEM/F-12 (SigmaAldrich) containing $10 \%$ FBS, penicillin, streptomycin, and amphotericin B was supplemented with insulin, transferrin, hydrocortisone, phosphoethanolamine, cholera toxin, ethanolamine, bovine pituitary extract, and BSA. The cells were maintained in a humidified $5 \% \mathrm{CO}_{2}$ incubator at $37^{\circ} \mathrm{C}$ until they adhered.

\section{Western blot analysis}

Lung tissues or cultured airway epithelial cells were homogenized in the presence of protease inhibitors to obtain extracts of proteins. Protein concentrations were determined using the Bradford reagent (Bio-Rad Laboratories Inc., Hercules, CA). Samples (30 $\mu \mathrm{g}$ of protein per lane) were loaded on a $12 \%$ SDS-PAGE gel. After electrophoresis at $120 \mathrm{~V}$ for $90 \mathrm{~min}$, separated proteins were transferred to PVDF membranes (GE Healthcare, Little Chalfont, Buckinghamshire, UK) by the wet transfer method ( $250 \mathrm{~mA}, 90 \mathrm{~min})$. Nonspecific sites were blocked with $5 \%$ non-fat dry milk in Tris-buffered saline Tween 20 (25 mM Tris, $\mathrm{pH} 7.5,150 \mathrm{mM} \mathrm{NaCl}$, and $0.1 \%$ Tween 20) for 1 $\mathrm{h}$, and the blots were then incubated with an anti-Cx37 Ab (Alpha Diagnostic International Inc., San Antonio, TX), anti-IL-4 Ab (Serotec Ltd, Oxford, UK), anti-IL-5 Ab (Santa Cruz Biotechnology, Santa Cruz, CA), anti-IL-13 Ab (R\&D Systems, Inc., Minneapolis, MN), anti-intercellular adhesion molecule-1 (ICAM-1) Ab (Santa Cruz Biotechnology), and anti-vascular cell adhesion molecule-1 (VCAM-1) Ab (Santa Cruz Biotechnology), anti-eotaxin Ab (Abcam Ltd., Cambridge, UK), or anti-RANTES Ab (Abcam Ltd.) overnight at $4^{\circ} \mathrm{C}$. Anti-rabbit or anti-mouse HRP conjugated IgG was used to detect binding of antibodies. The membranes were stripped and reblotted with antiactin Ab (Sigma-Aldrich) to verify equal loading of protein in each lane. The binding of the specific antibodies was visualized by exposing to photographic film after treating with enhanced chemiluminescence system reagents (GE Healthcare).

\section{RNA isolation and RT-PCR}

Total RNA from lung tissues was isolated using a rapid extraction method (TRI-Reagent) as previously described (Chomczynski and Sacchi, 1987). RNA was quantified by measuring absorption at $260 \mathrm{~nm}$ and stored at $-80^{\circ} \mathrm{C}$ until use. Total RNA 
(4 $\mu \mathrm{g}$ ) was reverse-transcribed to cDNA in a buffer containing $20 \mathrm{mM}$ Tris- $\mathrm{HCl}(\mathrm{pH} 8.4), 50 \mathrm{mM} \mathrm{KCl}, 5$ $\mathrm{mM} \mathrm{MgCl}$, $10 \mathrm{mM}$ DTT; $0.5 \mu \mathrm{g}$ random hexanucleotide primers, $2.5 \mathrm{mM}$ dNTP, $40 \mathrm{U}$ RNase inhibitor, and $50 \mathrm{U} / \mu$ l SuperScript II RT (Invitrogen, Carlsbad, CA), in a final volume of $20 \mu \mathrm{l}$. This mixture was incubated for $50 \mathrm{~min}$ at $42^{\circ} \mathrm{C}$ and then digested with $2 \mathrm{U} / \mu \mathrm{l}$ E. coli RNase $\mathrm{H}$ for $20 \mathrm{~min}$ at $37^{\circ} \mathrm{C}$. The first-strand cDNAs were used for PCR amplification of $\mathrm{C} \times 37$ or the housekeeping gene, GAPDH. PCR amplification was performed by mixing $3 \mu \mathrm{l}$ of the reverse transcription reaction mixture with $47 \mu$ l of buffer containing $2.5 \mathrm{U}$ of Taq DNA polymerase (Promega, Madison, WI) and 30 pmol of specific primer pairs for mouse cDNA of Cx37 or GAPDH, designed from published mouse gene sequences. The primers used were as follows: Cx37 (predicted length 136 bp) sense: 5'AGCTCTGCATCCAAGAAGCAGTA-3', antisense: 5'AGTTGTCTCTGAGGTGCCTTTGA-3' and GAPDH (predicted length $609 \mathrm{bp}$ ) sense: 5'-GCCATCAACGACCCCTTCATTGAC-3', antisense: 5'-ACGGAAGGCCATGCCAGTGAGCTT-3'. PCR reactions were performed in a thermocycler (GeneAmp ${ }^{\mathbb{R}}$ PCR System 2400, Applied Biosystems, Foster City, CA) using the following reaction conditions; after an initial incubation for $2 \mathrm{~min}$ at $95^{\circ} \mathrm{C}$, samples were subjected to 35 cycles of $1 \mathrm{~min}$ at $94^{\circ} \mathrm{C}, 2 \mathrm{~min}$ at $54^{\circ} \mathrm{C}(\mathrm{GAPDH})$ or $68^{\circ} \mathrm{C}(\mathrm{C} \times 37)$ and $1 \mathrm{~min}$ at $72^{\circ} \mathrm{C}$. A final extension step at $72^{\circ} \mathrm{C}$ for 10 min was performed. The RT-PCR products were electrophoretically fractioned on $2 \%$ agarose gels stained with ethidium bromide. DNA bands were visualized under UV light.

\section{Quantitative real-time RT-PCR}

Quantitative RT-PCR analysis was performed using the LightCycler $^{\circledR}$ FastStart DNA Master SYBR Green I (Roche Diagnostics, Mannheim, Germany). The sequences of primers used were as follows: Cx37 sense: 5'-AGCTCTGCATCCAAGAAGCAGTA-3', antisense: 5'-AGTTGTCTCTGAGGTGCCTTTGA-3' and $\beta$-actin sense: 5'-CAGATCATGTTTGAGACCTTC-3', antisense: 5'-ACTTCATGATGGAATTGAATG-3'. Calculation of the relative mRNA levels of each sample was performed according to the manufacturer's protocol. The data have been normalized to the expression of $\beta$-actin.

\section{Histology and immunohistochemistry}

At $72 \mathrm{~h}$ after the last challenge, lungs were removed from the mice after sacrifice. Before the lungs were removed, the lungs and trachea were filled intratracheally with a fixative $(0.8 \%$ formalin,
$4 \%$ acetic acid) using a ligature around the trachea. Lung tissues were fixed with $10 \%$ (vol/vol) neutral buffered formalin. The specimens were dehydrated and embedded in paraffin. For histological examination, 4- $\mu \mathrm{m}$ sections of fixed embedded tissues were cut on a Leica model 2165 rotary microtome (Leica, Nussloch, Germany), placed on glass slides, deparaffinized, and stained sequentially with hematoxylin 2 and eosin-Y (Richard-Allan Scientific, Kalamazoo, MI) stain. Inflammation score was graded by three independent blinded investigators. The degree of peribronchial and perivascular inflammation was evaluated on a subjective scale of 0 to 3 , as described elsewhere (Tournoy et al., 2000). For immunohistochemistry of $\mathrm{Cx} 37$, the deparaffinized 4- $\mu \mathrm{m}$ sections were incubated sequentially in accordance with the R. T. U. Vectastain Universal Quick kit instruction from Vector Laboratories (Burlingame, CA). Briefly, the slides were incubated in Endo/Blocker (Biomeda, Foster City, CA) for $5 \mathrm{~min}$ and then in pepsin solution for $4 \mathrm{~min}$ at $40^{\circ} \mathrm{C}$. The slides were incubated in normal horse serum for $15 \mathrm{~min}$ at room temperature. The slides were then probed with an anti-Cx37 Ab (Alpha diagnostic International Inc.), overnight at $4^{\circ} \mathrm{C}$, and were incubated with prediluted biotinylated panspecific IgG for $10 \mathrm{~min}$. The slides were incubated in streptavidin/peroxidase complex reagent for 5 min, and then in 3-amino-9-ethylcarbazole substrate kit for $12 \mathrm{~min}$. For the control, sections of lung tissue from mice were treated without the primary $A b$ under the same conditions. After immunostaining, the slides were counterstained with Gill's hematoxylin in $20 \%$ ethylene glycol for $1 \mathrm{~min}$ and then mounted with Aqueous Mounting Medium (InnoGenex, San Ramon, CA) and photomicrographed (Vanox T; Olympus, Tokyo, Japan).

\section{Determination of airway responsiveness}

Airway responsiveness was also assessed as a change in airway function after challenge with aerosolized methacholine via airways, as described elsewhere (Takeda et al., 1997). Anesthesia was achieved with $80 \mathrm{mg} / \mathrm{kg}$ of pentobarbital sodium injected intraperitoneally. The trachea was then exposed through midcervical incision, tracheostomized, and an 18-gauge metal needle was inserted. Mice were connected to a computer-controlled small animal ventilator (flexiVent, SCIREQ, Montreal, Canada). The mouse was quasi-sinusoidally ventilated with nominal tidal volume of 10 $\mathrm{ml} / \mathrm{kg}$ at a frequency of 150 breaths $/ \mathrm{min}$ and a positive end-expiratory pressure of $2 \mathrm{~cm} \mathrm{H} \mathrm{H}_{2} \mathrm{O}$ to achieve a mean lung volume close to that during 
spontaneous breathing. This was achieved by connecting the expiratory port of the ventilator to water column. Methacholine aerosol was generated with an in-line nebulizer and administered directly through the ventilator. To determine the differences in airway response to methacholine, each mouse was challenged with methacholine aerosol in increasing concentrations (2.5 to 50 $\mathrm{mg} / \mathrm{ml}$ in saline). After each methacholine challenge, the data of calculated airway resistance $\left(R_{L}\right)$ were continuously collected. Maximum values of $R_{L}$ were selected to express changes in airway function which was represented as a percentage change from baseline after saline aerosol.

\section{Measurement of Th2 cytokines}

Levels of IL-4, IL-5, and IL-13 were quantified in the supernatants of BAL fluids by enzyme immunoassays according to the manufacturer's protocol (IL-4; BioSource International, Inc. Camarillo, CA, IL-5; Endogen, Inc., Woburn, MA, IL-13; R\&D Systems, Inc.). Sensitivities for IL-4, IL-5, and IL-13 assays were 5,5 , and $1.5 \mathrm{pg} / \mathrm{ml}$, respectively.

\section{Densitometric analysis and statistics}

All immunoreactive signals were analyzed by densitometric scanning (Gel Doc XR; Bio-Rad Laboratories Inc.). Data were expressed as mean \pm SEM. Statistical comparisons were performed using one-way ANOVA followed by the Scheffe's test. Pearson's correlation was calculated to assess the correlation between data. Significant differences between two groups were determined using the unpaired Student's $t$ test. Statistical significance was set at $P<0.05$.

\section{Results}

\section{Cx37 protein levels in lung tissues of OVA-sensitized and -challenged mice}

Western blot analysis revealed that $\mathrm{C} \times 37$ protein levels in lung tissues were decreased approximately 0.89-, 0.51-, 0.36-, 0.24-, and 0.19-fold at 1 , $7,24,48$, and $72 \mathrm{~h}$ after OVA inhalation, respectively, compared with the prechallenge period (Figure 1). In contrast, no significant changes in the $\mathrm{C} \times 37$ protein level were observed after saline inhalation.

\section{Cx37 mRNA expression in lung tissues of OVA-sensitized and -challenged mice}

Real-time RT-PCR analysis revealed that Cx37
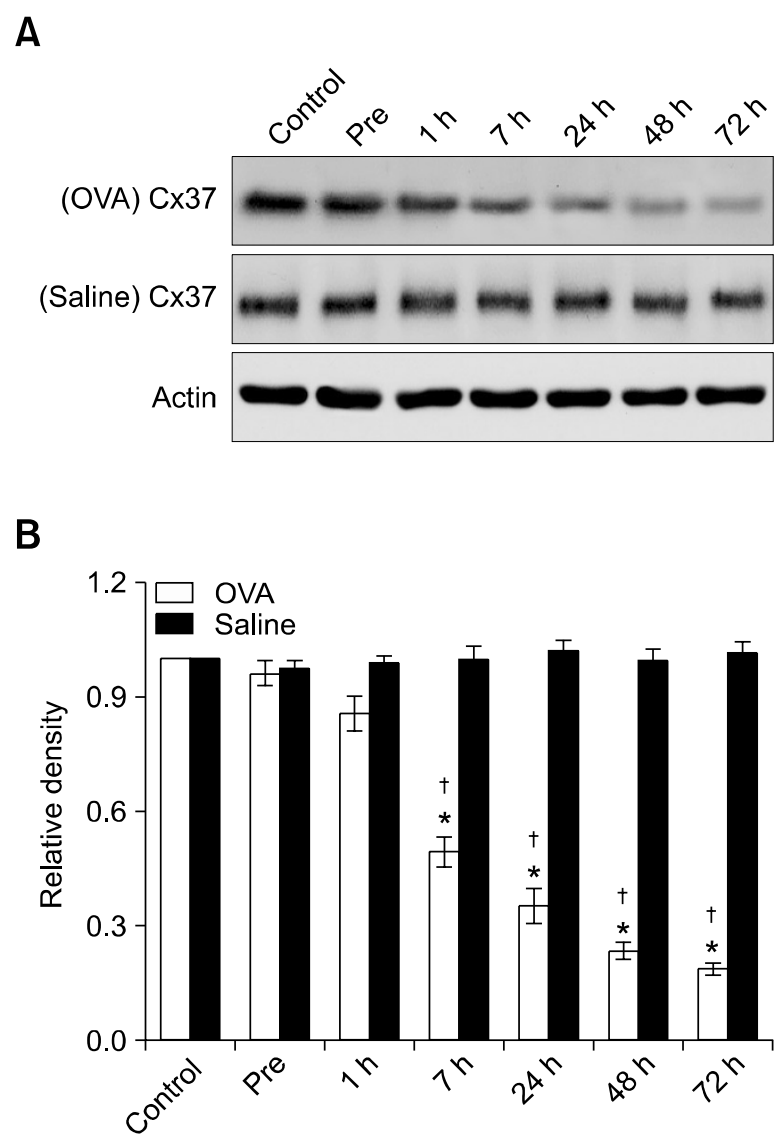

Figure 1. Levels of Cx37 protein in lung tissues of OVA-sensitized and -challenged mice. Sampling was performed in lung tissues from sensitized mice challenged with OVA or saline. (A) Western blot analyses of Cx37 protein. (B) Densitometric analyses are presented as the relative ratio of $\mathrm{C} \times 37$ to actin. The relative ratio of $\mathrm{C} \times 37$ in the lung tissues of control group is arbitrarily presented as 1 . Data represent mean \pm SEM from 8 mice per group. $1,7,24,48$, and $72 \mathrm{~h}$ are time periods after the last challenge. Control, no treatment; Pre, $1 \mathrm{~h}$ before the first challenge; ${ }^{+} P<0.05$ versus Pre; ${ }^{*} P<0.05$ versus saline inhalation.

mRNA expression was decreased approximately 0.58-, 0.44-, 0.32-, 0.26-, and 0.26-fold at 1, 7, 24, 48 , and $72 \mathrm{~h}$ after OVA inhalation, respectively, compared with the prechallenge period (Figure 2). In contrast, no significant changes in the $\mathrm{C} \times 37$ mRNA expression were observed after saline inhalation.

\section{Localization of immunoreactive Cx37 in lung tissues of OVA-induced allergic airway disease}

Immunoreactive Cx37 localized in epithelial layers around the bronchioles of control mice (Figure 3A), which dramatically disappeared in allergen-induced airway inflammatory lungs (Figure 3B). 
A

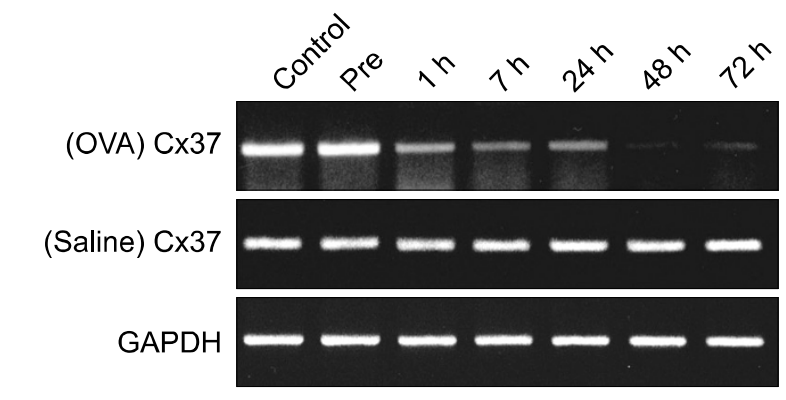

B

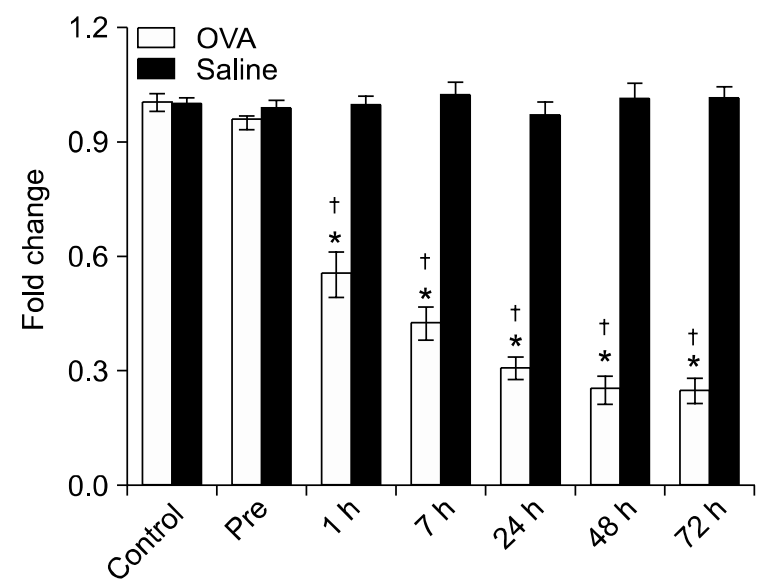

Figure 2. Levels of $\mathrm{Cx} 37 \mathrm{mRNA}$ in lung tissues of OVA-sensitized and -challenged mice. Sampling was performed in lung tissues from sensitized mice challenged with OVA or saline. (A) Representative RT-PCR analysis of $\mathrm{C} \times 37$ mRNA expression. (B) Quantitative analysis of $\mathrm{C} \times 37$ mRNA expression by means of real-time RT-PCR. The relative ratio of Cx37 in the lung tissues of control group is arbitrarily presented as 1 . Data represent mean \pm SEM from 8 mice per group. 1, 7, 24, 48, and $72 \mathrm{~h}$ are time periods after the last challenge. Control, no treatment; Pre, $1 \mathrm{~h}$ before the first challenge; ${ }^{\dagger} P<0.05$ versus Pre; ${ }^{*} P<0.05$ versus saline inhalation.

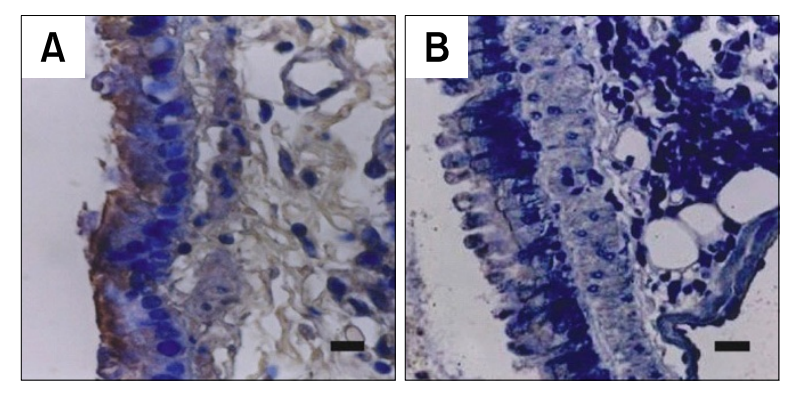

Figure 3. Localization of immunoreactive $\mathrm{C} \times 37$ in lung tissues of OVA-sensitized and -challenged mice. Sampling was performed at $72 \mathrm{~h}$ after the last challenge in lung tissues from sensitized mice challenged with saline (A) and from sensitized mice challenged with OVA (B). Representative light microscopy shows Cx37-positive cells in the bronchioles. The dark brown color indicates $\mathrm{C} \times 37$-positive cells. Bars indicate $10 \mu \mathrm{m}$.
A

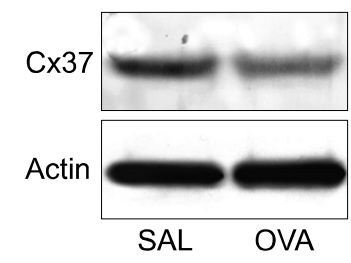

B

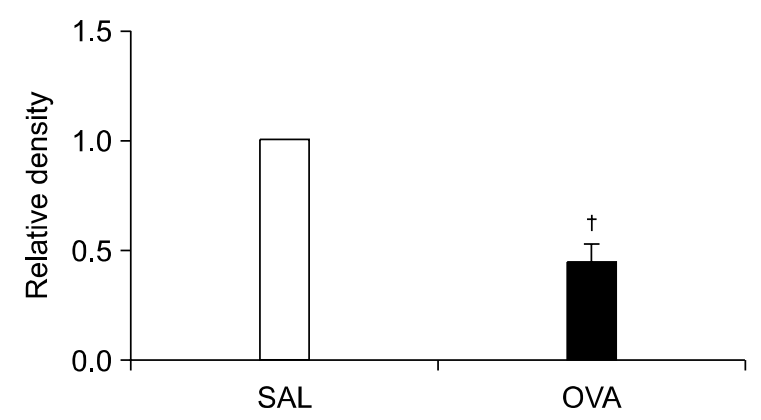

Figure 4. Levels of $\mathrm{C} \times 37$ protein in tracheal epithelial cells. (A) Western blot analyses of $\mathrm{Cx} 37$ protein in tracheal epithelial cells of saline-sensitized and -challenged mice (SAL) and OVA-sensitized and -challenged mice (OVA). (B) Densitometric analyses are presented as the relative ratio of $\mathrm{C} \times 37$ to actin. The relative ratio of $\mathrm{C} \times 37$ in the epithelial cells of SAL is arbitrarily presented as 1 . Data represent mean \pm SEM from 5 independent experiments. ${ }^{\dagger} P<0.05$ versus SAL.

\section{Cx37 protein levels in primary murine tracheal epithelial cells}

Western blot analysis revealed that $\mathrm{C} \times 37$ protein levels in tracheal epithelial cells were significantly decreased after OVA inhalation compared with the levels in control mice (Figure 4).

\section{Cellular changes in BAL fluids after OVA inhalation}

Numbers of total cells, eosinophils, and neutrophils were increased in a time-dependent manner, reaching maximum levels in BAL fluids at $48 \mathrm{~h}$ after OVA inhalation, and the numbers of total cells, eosinophils, lymphocytes, and neutrophils were significantly greater from $24 \mathrm{~h}$ to $72 \mathrm{~h}$ after OVA inhalation compared with cell numbers before the inhalation or those in the control group (Figure $5 A)$. The levels of $\mathrm{C} \times 37$ protein in lung tissues showed significantly negative correlations with the numbers of total cells $(r=-0.825, P<0.05)$, eosinophils $(r=-0.736, P<0.05)$, lymphocytes $(r$ $=-0.819, P<0.05)$, and neutrophils $(r=-0.761$, $P<0.05$ ) in BAL fluids (Figure 5B, C, D, and E). 
A

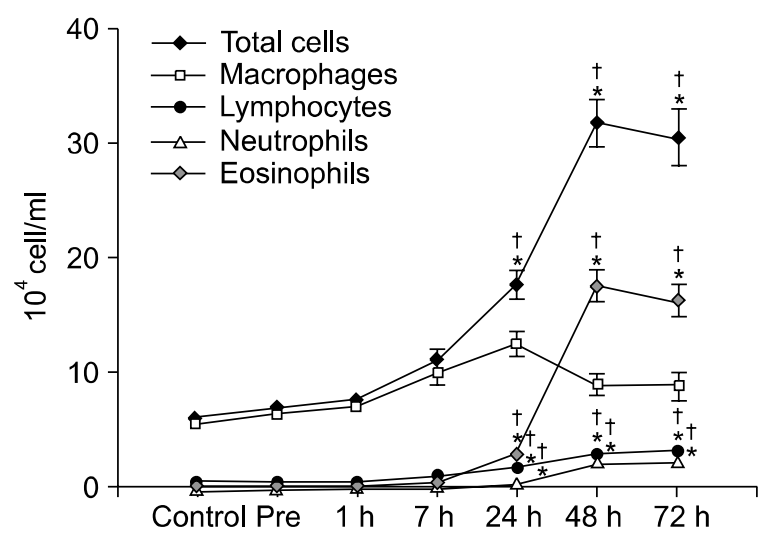

B

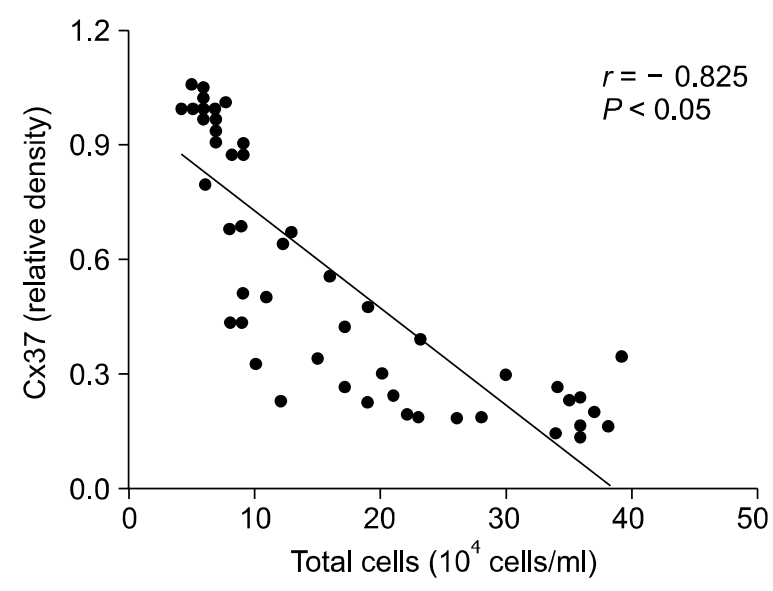

D

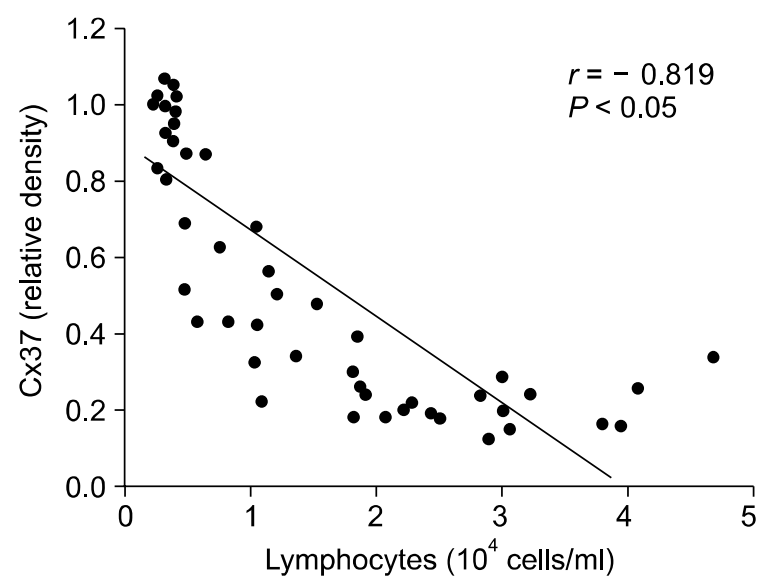

C

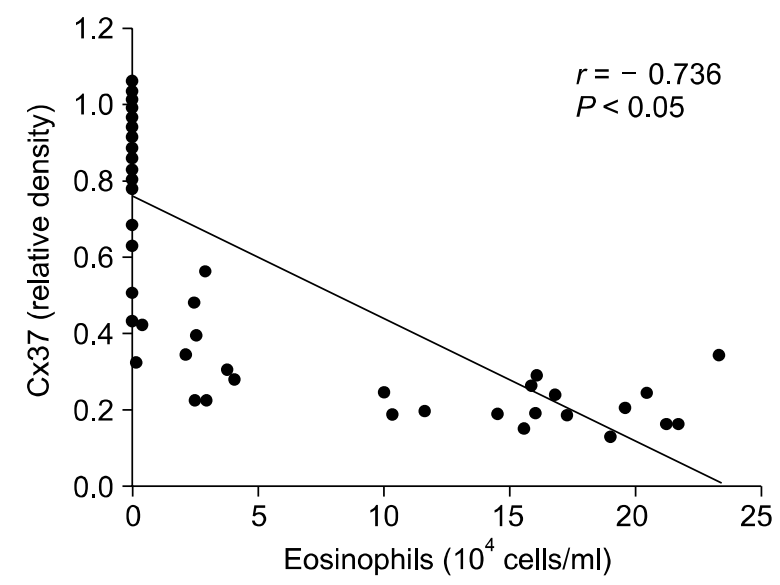

E

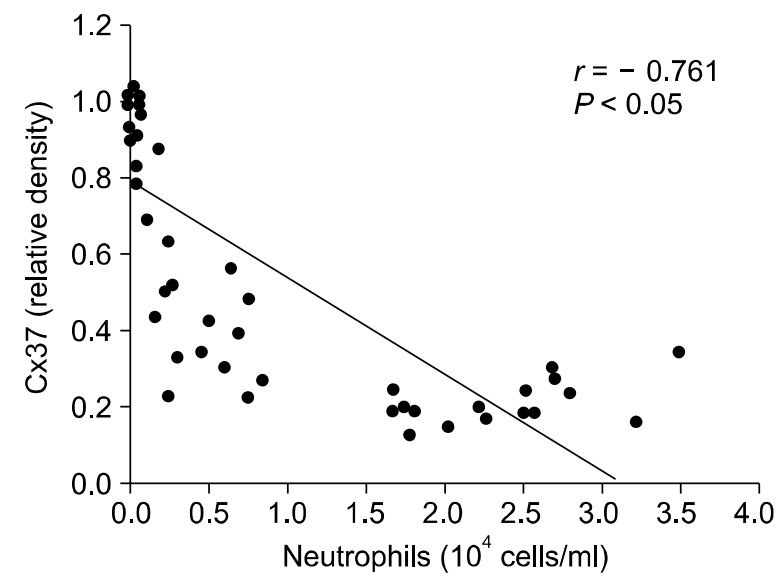

Figure 5. Cellular changes in BAL fluids after OVA inhalation. (A) Effect of OVA challenge on total cells and differential cellular components in BAL fluids. The numbers of each cellular component of BAL fluids from mice were counted at indicated time after the last challenge with OVA or saline. 1,7,24, 48, and $72 \mathrm{~h}$ are time periods after the last challenge. Data represent mean \pm SEM from 8 mice per group. Control, no treatment; Pre, $1 \mathrm{~h}$ before the first challenge; ${ }^{\dagger} P<0.05$ versus Pre; ${ }^{*} P<0.05$ versus Control. (B-E) Correlations of $\mathrm{C} \times 37$ protein levels in lung tissues with numbers of total cells $(\mathrm{B})$, eosinophils $(C)$, lymphocytes (D), and neutrophils (E) in BAL fluids. 


\section{Pathological changes of OVA-sensitized and -challenged mice}

Histologic analyses revealed typical pathologic features of asthma in the OVA-exposed mice. Numerous inflammatory cells, including eosinophils, infiltrated around the bronchioles, the airway epithelium was thickened, and mucus and debris had accumulated in the lumen of bronchioles (Figure 6B). In contrast, no significant changes were observed in the control mice (Figure 6A). The scores of peribronchial, perivascular, and total lung inflammation were increased significantly at $72 \mathrm{~h}$ after OVA inhalation compared with scores after saline inhalation (Figure 6C).

\section{Airway responsiveness after OVA inhalation}

Airway responsiveness was assessed as a percent increase of $R_{L}$ in response to increasing doses of methacholine. In OVA-sensitized and -challenged mice, the dose-response curve of percent $R_{L}$ shifted to the left compared with that of control mice (Figure 7A). In addition, the percent $R_{L}$ produced by methacholine administration at dose of $50 \mathrm{mg} / \mathrm{ml}$ increased significantly in the OVAsensitized and -challenged mice compared with the controls. These results indicate that OVA induce airway hyperresponsiveness. In addition, the levels of $\mathrm{C} \times 37$ protein in lung tissues showed significantly negative correlation with the values of $\mathrm{R}_{\mathrm{L}}(r=-0.883, P<0.05)$ (Figure 7B).

A

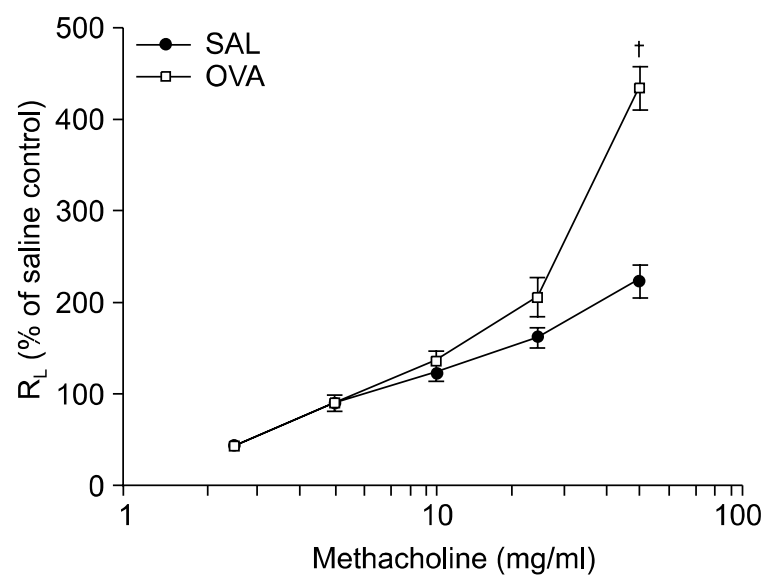

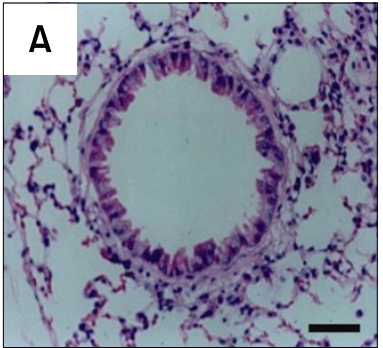

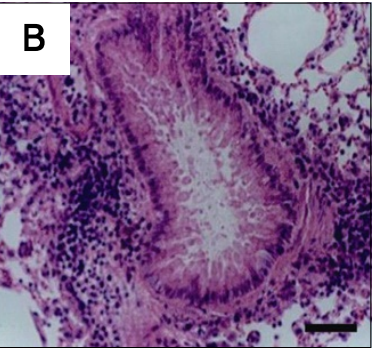

C

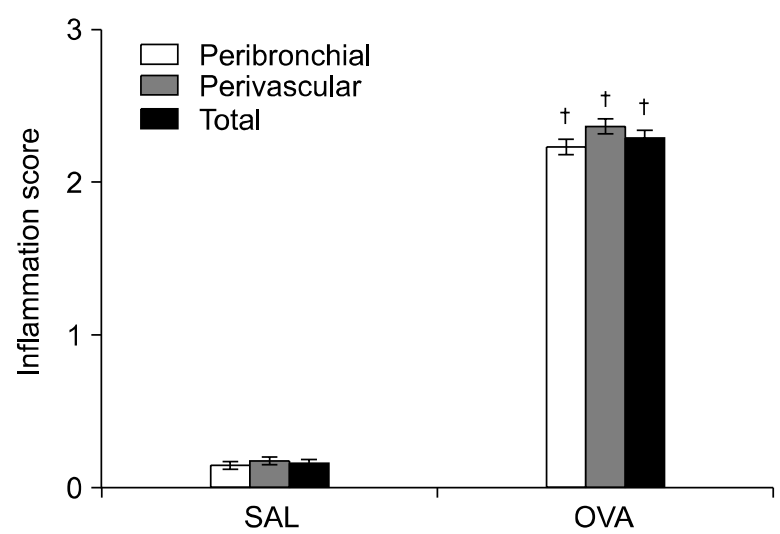

Figure 6. Pathologic changes after OVA inhalation. (A and $B$ ) Representative hematoxylin and eosin-stained sections of the lungs. Sampling was performed at $72 \mathrm{~h}$ after the last challenge in saline-sensitized and -challenged mice $(\mathrm{A})$ and OVA-sensitized and -challenged mice (B). Bars indicate $50 \mu \mathrm{m}$. (C) Peribronchial, perivascular, and total lung inflammation. Total lung inflammation was defined as the average of the peribronchial and perivascular inflammation scores in saline-sensitized and -challenged mice (SAL) or OVA-sensitized and -challenged mice (OVA). Data represent mean \pm SEM from 8 mice per group. ${ }^{\dagger} P<$ 0.05 versus $S A L$.
B

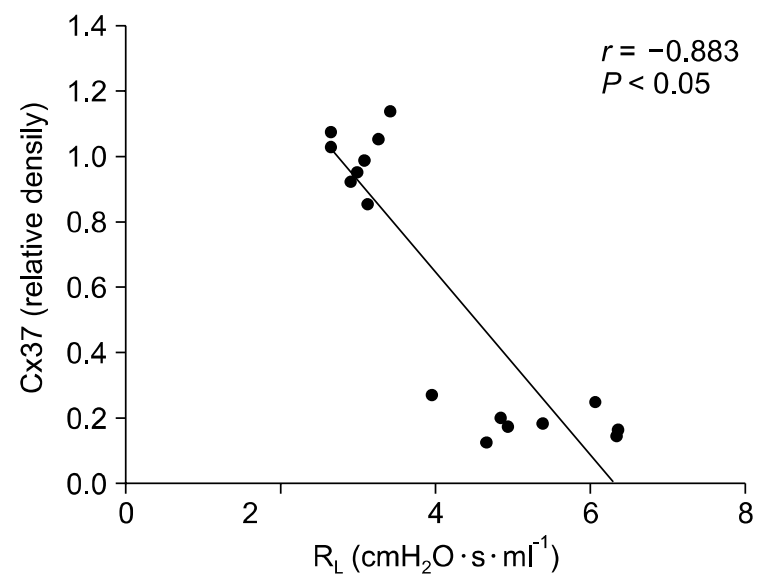

Figure 7. Airway responsiveness after OVA inhalation. (A) Effect of OVA challenge on airway responsiveness. Airway responsiveness was measured at $72 \mathrm{~h}$ after the last challenge in saline-sensitized and -challenged mice (SAL) or OVA-sensitized and -challenged mice (OVA). Data represent mean \pm SEM from 8 mice per group. ${ }^{\dagger} P<0.05$ versus SAL. (B) Correlation between the levels of $C \times 37$ protein in lung tissues and airway responsiveness. Data of airway responsiveness were the values of $R_{L}$ measured by methacholine challenge at dose of $50 \mathrm{mg} / \mathrm{ml}$. 
A

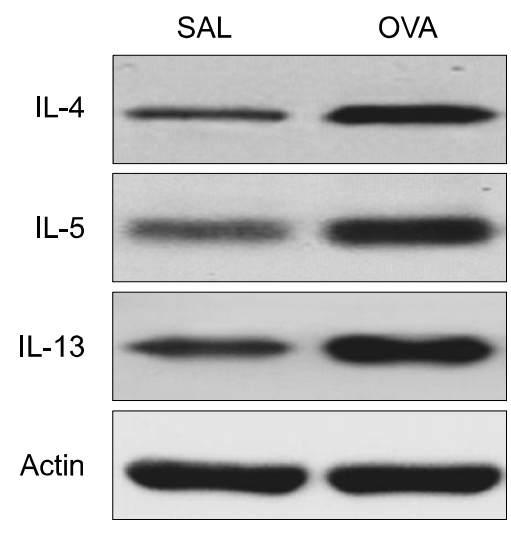

D

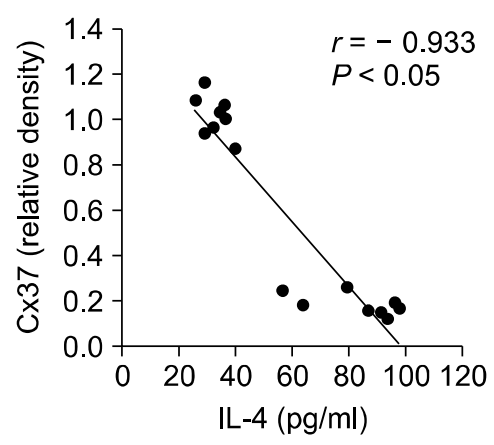

B

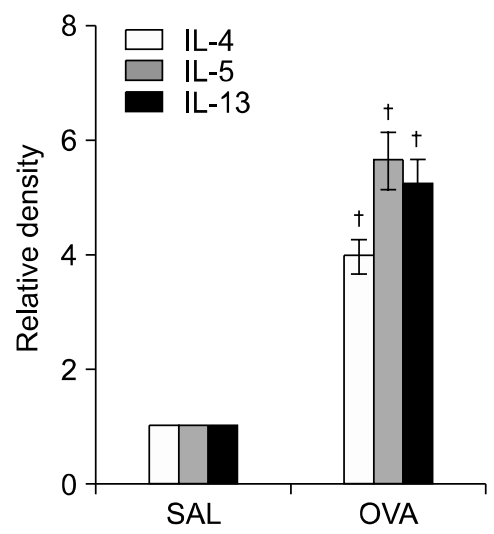

E

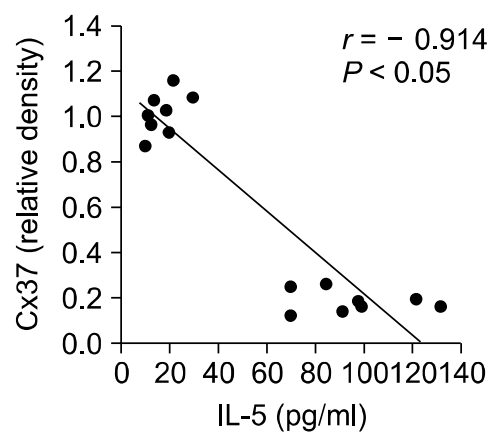

C

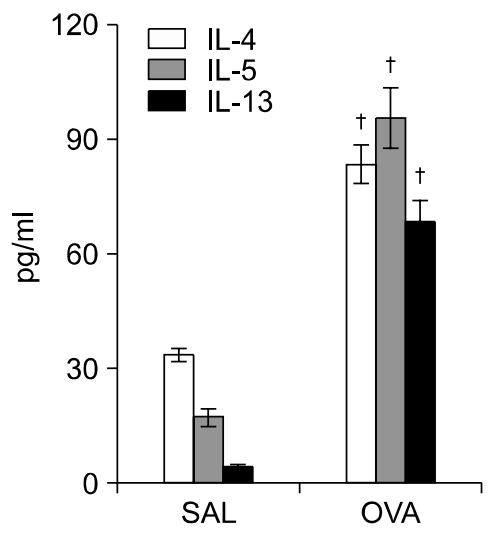

F

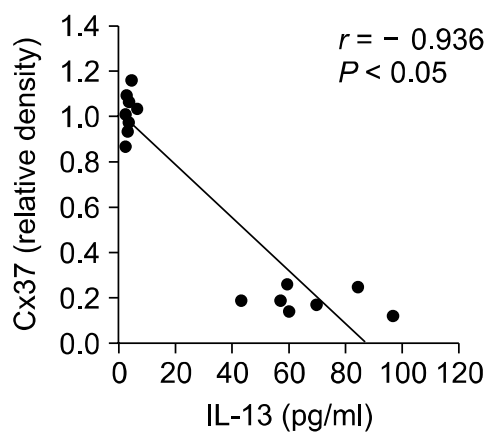

Figure 8. Levels of Th2 cytokines in lung tissues and BAL fluids of OVA-sensitized and -challenged mice. Sampling was performed at $72 \mathrm{~h}$ after the last challenge in saline-sensitized and -challenged mice (SAL) and OVA-sensitized and -challenged mice (OVA). (A) Western blotting of IL-4, IL-5, and IL-13 in lung tissues. (B) Densitometric analyses are presented as the relative ratio of $\mathrm{IL}-4$, IL-5, and IL-13 to actin. The relative ratio of each molecule in the lung tissues of SAL is arbitrarily presented as 1. (C) Enzyme immunoassay of IL-4, IL-5, and IL-13 in BAL fluids. Data represent mean \pm SEM from 8 mice per group. ${ }^{\dagger} P<0.05$ versus SAL. (D-F) Correlations of $C \times 37$ protein levels in lung tissues with levels of IL-4 (D), IL-5 (E), and IL-13 (F) in BAL fluids.

\section{Levels of Th2 cytokines (IL-4, IL-5, and IL-13) in lungs of OVA-sensitized and -challenged mice}

Western blot analysis revealed that the protein levels of IL-4, IL-5, and IL-13 in lung tissues were significantly increased at $72 \mathrm{~h}$ after OVA inhalation compared with the levels in the control mice (Figure 8A and $\mathrm{B}$ ). Consistent with the results obtained from the Western blot analysis, enzyme immunoassays also showed significant increases in the levels of IL-4, IL-5, and IL-13 in BAL fluids at $72 \mathrm{~h}$ after OVA inhalation compared with the levels in the control mice (Figure $8 \mathrm{C}$ ). The levels of $\mathrm{C} \times 37$ protein in lung tissues showed significantly negative correlations with the levels of IL-4 $(r=-0.933$, $P<0.05)$, IL-5 $(r=-0.914, P<0.05)$, and IL-13 $(r=-0.936, P<0.05)$ in BAL fluids (Figure 8D, E, and $F$ ).

\section{Levels of adhesion molecules (ICAM-1 and VCAM-1) and chemokines (eotaxin and RANTES) in lung tissues of OVA-sensitized and -challenged mice}

Western blot analysis revealed that the protein levels of ICAM-1, VCAM-1, eotaxin, and RANTES in lung tissues were significantly increased at $72 \mathrm{~h}$ after OVA inhalation compared with the levels in the control mice (Figure 9).

\section{Discussion}

To our knowledge, this report is the first to describe the change of $\mathrm{Cx} 37$ in a murine model of allergeninduced airway inflammation. Gap junctions contain channels that allow the intercellular passage of ions and small molecules (Giepmans, 2004). At least twenty different Cxs have been reported, and they show different patterns of tissue distribution and developmental expression, as well as forming 
A

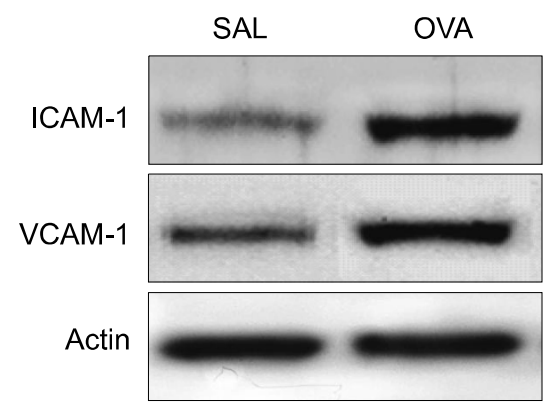

C

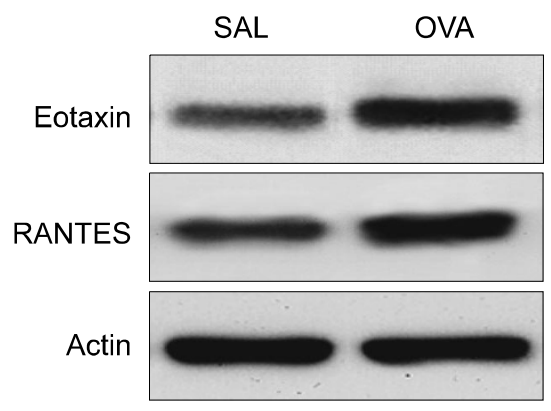

B

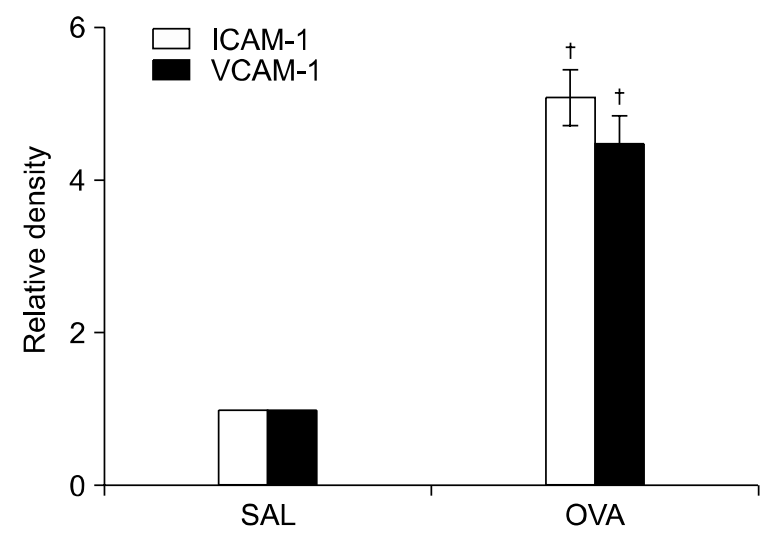

D

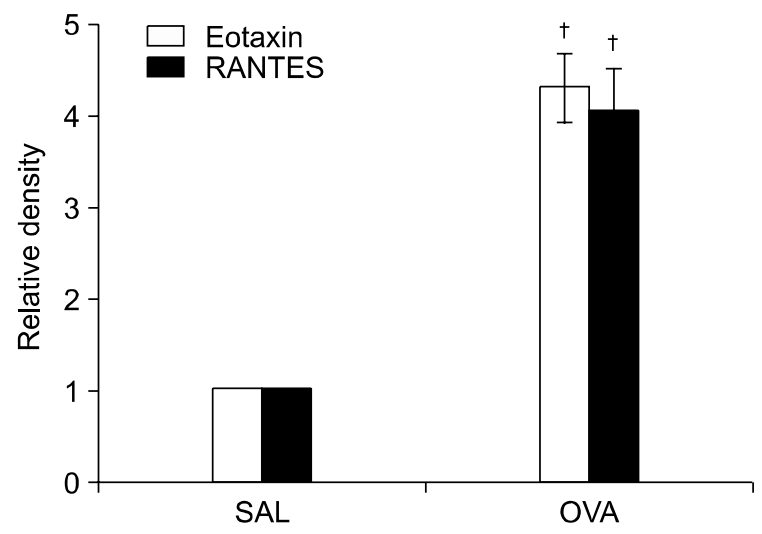

Figure 9. Levels of adhesion molecules and chemokines in lung tissues of OVA-sensitized and -challenged mice. Sampling was performed at $72 \mathrm{~h}$ after the last challenge in saline-sensitized and -challenged mice (SAL) and OVA-sensitized and -challenged mice (OVA). (A) Western blotting of ICAM-1 and VCAM-1 in lung tissues. (B) Densitometric analyses are presented as the relative ratio of ICAM-1 and VCAM-1 to actin. (C) Western blotting of eotaxin and RANTES in lung tissues. (D) Densitometric analyses are presented as the relative ratio of eotaxin and RANTES to actin. The relative ratio of each molecule in the lung tissues of SAL is arbitrarily presented as 1 . Data represent mean \pm SEM from 8 mice per group. ${ }^{\dagger} P<0.05$ versus SAL.

channels with different biophysical characteristics. Unlike some other gap junction proteins, Cx37 is a subunit gap junction protein which exhibits limited expression in a few organs of the body including heart, lung, uterus, and ovary. Endothelial cells are a predominant cell type shown to express Cx37 (Reed et al., 1993; Carter et al., 1996; Yeh et al., 1997). Cx37 may also play important roles in other cell types in organs such as the ovary where it is found between cumulus cells and the oocyte; Cx37 knock out mice exhibit female infertility due to impaired maturation of ovarian follicles (Reed et al., 1993). Cx37 forms some of the most voltagesensitive channels among known gap junctions and shows conductance, permeability, and gating properties that are distinct from other Cxs (Reed et al., 1993; Veenstra et al., 1994). Cx37 has been detected abundantly in lung including endothelial cells, fibroblastic cells, and airway smooth muscle cells (Willecke et al., 1991; Nakamura et al., 1999).

Many studies on $\mathrm{Cx}$ expression in alveolar tissue and alveolar epithelial cell cultures have uncovered complex patterns of protein expression with at least six different Cxs: Cx26, Cx32, Cx37, Cx40, Cx43, and Cx46 (Haefliger et al., 1992; Lee et al., 1997; Carson et al., 1998; Abraham et al., 1999, 2001; Guo et al., 2001; Isakson et al., 2001a, b). Changes in Cx expression in alveolar epithelial cells have been associated with developing or post-injury airways (Carson et al., 1995, 1998; Abraham et al., 2001), phenotypic changes inherent in alveolar cell culture (Lee et al., 1997; Abraham et al., 1999; Isakson et al., 2001b), or changes in extracellular signaling molecules, including growth factors and matrix proteins (Abraham et al., 1999; Alford and Rannels, 2001; 
Guo et al., 2001; Isakson et al., 2001b). Although alveolar epithelial cells display a complex regulation of Cx expression, it is unclear how or whether gap junctional communication contributes to physiologic changes in the lung.

In this study, Cx37 protein and mRNA expression were decreased in lung tissues of a murine model of OVA-induced allergic airway disease. Immunoreactive Cx37 localized in epithelial layers around the bronchioles of control mice, which dramatically disappeared in allergen-induced asthmatic lungs. In addition, Cx37 protein levels in tracheal epithelial cells were significantly decreased after OVA inhalation compared with the levels in control mice. These findings suggest that the epithelial layer is one of the sites of $\mathrm{C} \times 37$ expression in lungs. Our present study with OVAinduced murine model of allergic airway disease has revealed the following typical pathophysiological features: airway hyperresponsiveness, airway inflammation, and increased levels of Th2 cytokines (IL-4, IL-5, and IL-13), adhesion molecules (ICAM-1 and VCAM-1), and chemokines (eotaxin and RANTES) in lungs. These features of asthma induced in a mouse model are similar to the human asthma (National Institutes of Health et al., 1995; Lilly et al., 2005) and make the mouse model suitable for investigations of the pathophysiology and immunology of asthma. In this study, the levels of Cx37 protein in lung tissues showed significantly negative correlations with airway inflammation, airway responsiveness, and levels of Th2 cytokines in lungs. These findings suggest that alterations in Cx37 levels are associated with the asthma phenotype.

Previous studies have reported that inhibitors of Cx37 channels increase leukocyte adhesion (Zahler et al., 2003; Wong et al., 2006; Chanson and Kwak, 2007). In addition, the recruitment of Cx37-deficient inflammatory cells is enhanced compared with that of Cx37-expressing cells, and restoration of $\mathrm{C} \times 37$ expression in $\mathrm{C} \times 37$-deficient cell line by transfection of Cx37 cDNA decreases leukocyte adhesion (Wong et al., 2006). These studies suggest that $\mathrm{C} \times 37$ is involved in regulating recruitment and adhesion of inflammatory cells. Adhesion molecules (ICAM-1 and VCAM-1) and chemokines (eotaxin and RANTES) play central roles in asthma through regulating adhesion and migration of inflammatory cells into airway (Romagnani, 2002; Yusuf-Makagiansar et al., 2002). Our present study has shown that the protein levels of adhesion molecules (ICAM-1 and VCAM-1) and chemokines (eotaxin, and RANTES) were increased. In addition, the levels of $\mathrm{C} \times 37$ protein correlated inversely with the levels of these molecules in lung tissues (data not shown). Adhesion molecules and chemokines are expressed by various airway cells including eosinophils, bronchial epithelium cells, endothelial cells, T cells, mast cells, and alveolar macrophages (Wardlaw et al., 1994; Bisset and Schmid-Grendelmeier, 2005). Expression of ICAM-1 or VCAM-1 is modulated by Th2 cytokines in airway inflammation (Bochner et al., 1995; Striz et al., 1999; Henderson et al., 2000). Th2 cytokines are also able to stimulate the production of chemokines in airway cells (Mochizuki et al., 1998; Li et al., 1999; Teran et al., 1999; Bisset and Schmid-Grendelmeier, 2005). In this study, the levels of $\mathrm{C} \times 37$ protein in lung tissues showed significantly negative correlations with the numbers of airway inflammatory cells, which are the source of adhesion molecules or chemokines, and the levels of Th2 cytokines, which induce the expression of these molecules. Therefore, the increase in the expression of adhesion molecules and chemokines associated with decreased $\mathrm{C} \times 37$ levels may be due to the increased airway inflammation and Th2 cytokines levels in lungs of allergic airway disease.

In summary, we have shown that $\mathrm{C} \times 37$ expression was decreased in lung tissues of a murine model of allergic airway disease, which is mimicking human bronchial asthma, and that $\mathrm{C} \times 37$ was localized in airway epithelial cells. Moreover, levels of $\mathrm{C} \times 37$ protein in lung tissues showed significantly negative correlations with airway inflammation, airway responsiveness, and levels of Th2 cytokines in lungs. Our results suggest that alterations in Cx37 levels are associated with airway inflammation and bronchial hyperresponsiveness.

\section{Acknowledgments}

We thank professor Mie-Jae Im for critical readings of the manuscript. This work was supported by Korea Research Foundation Grant funded by Korea Government (MOEHRD, Basic Research Promotion Fund) (KRF-2005201-E00014), by a grant of the Korea Health 21 R\&D project, Ministry of Health and Welfare, Republic of Korea (A060169), by a grant of the Korea Science and Engineering Foundation (KOSEF) through the National Research Lab. Program funded by the Ministry of Science and Technology (ROA-2005-000-10052-0(2007)), and also by a grant from the Korea Health 21 R\&D Project (0412CR03-0704-0001).

\section{References}

Abraham V, Chou M, DeBolt K, Koval M. Phenotypic control 
of gap junctional communication by alveolar epithelial cells. Am J Physiol Lung Cell Mol Physiol 1999;276:L825-34

Abraham V, Chou ML, George P, Pooler P, Zaman A, Savani $\mathrm{RC}$, Koval M. Heterocellular gap junctional communication between alveolar epithelial cells. Am J Physiol Lung Cell Mol Physiol 2001;280:L1085-93

Alford AI, Rannels DE. Extracellular matrix fibronectin alters connexin43 expression by alveolar epithelial cells. Am J Physiol Lung Cell Mol Physiol 2001;280:L680-8

Bisset LR, Schmid-Grendelmeier P. Chemokines and their receptors in the pathogenesis of allergic asthma: progress and perspective. Curr Opin Pulm Med 2005;11:35-42

Bochner BS, Klunk DA, Sterbinsky SA, Coffman RL, Schleimer RP. IL-13 selectively induces vascular cell adhesion molecule-1 expression in human endothelial cells. J Immunol 1995;154:799-803

Carson JL, Collier AM, Hu SC, McLachlan JB. Variability in distribution and populations of gap junctions in ferret trachea during postnatal development. Am J Physiol 1995;268: L576-83

Carson JL, Reed W, Moats-Staats BM, Brighton LE, Gambling TM, Hu SC, Collier AM. Connexin 26 expression in human and ferret airways and lung during development. Am J Respir Cell Mol Biol 1998;18:111-9

Carter TD, Chen XY, Carlile G, Kalapothakis E, Ogden DO, Evans WH. Porcine aortic endothelial gap junctions identification and permeation by caged InsP3. J Cell Sci 1996;109:1765-73

Chanson M, Kwak BR. Connexin37: a potential modifier gene of inflammatory disease. J Mol Med 2007; 85:787-95

Chomczynski P, Sacchi N. Single-step method of RNA isolation by acid guanidium thiocyanate-phenol-chloroform extraction. Anal Biochem 1987;162:156-9

Giepmans BN. Gap junctions and connexin-interacting proteins. Cardiovasc Res 2004;62:233-45

Guo Y, Martinez-Williams C, Yellowley CE, Donahue HJ, Rannels DE. Connexin expression by alveolar epithelial cells is regulated by extracellular matrix. Am J Physiol Lung Cell Mol Physiol 2001;280:L191-202

Haefliger JA, Bruzzone R, Jenkins NA, Gilbert DJ, Copeland NG, Paul DL. Four novel members of the connexin family of gap junction proteins: molecular cloning, expression, and chromosome mapping. J Biol Chem 1992;267:2057-64

Henderson WR, Chi EY, Maliszewski CR. Soluble IL-4 receptor inhibits airway inflammation following allergen challenge in a mouse model of asthma. J Immunol 2000; 164:1086-95

Institute of Laboratory Animal Research, Commission of Life Sciences, National Research Council. Guide for the care and use of laboratory animals, 1996, National Acamedy Press, Washington, DC, USA

Isakson BE, Evans WH, Boitano S. Intercellular $\mathrm{Ca}^{2+}$ signaling in alveolar epithelial cells through gap junctions and by extracellular ATP. Am J Physiol Lung Cell Mol Physiol 2001a;280:L221-8
Isakson BE, Lubman RL, Seedorf GJ, Boitano S. Modulation of pulmonary alveolar type II cell phenotype and communication by extracellular matrix and KGF. Am J Physiol Cell Physiol 2001b;281:C1291-9

Jiang JX, Gu S. Gap junction- and hemichannel-independent actions of connexins. Biochim Biophys Acta 2005;1711: 208-14

Kwak YG, Song CH, Yi HK, Hwang PH, Kim JS, Lee KS, Lee $Y C$. Involvement of PTEN in airway hyperresponsiveness and inflammation in bronchial asthma. J Clin Invest 2003;111:1083-92

Lee KS, Kim SR, Park SJ, Park HS, Min KH, Jin SM, Lee MK, Kim UH, Lee YC. Peroxisome proliferator activated receptor-gamma modulates reactive oxygen species generation and activation of nuclear factor-kappaB and hypoxia-inducible factor 1 alpha in allergic airway disease of mice. J Allergy Clin Immunol 2006a;118:120-7

Lee KS, Park HS, Park SJ, Kim SR, Min KH, Jin SM, Li L, Lee YC. An antioxidant modulates expression of receptor activator of NF-kappaB in asthma. Exp Mol Med 2006b;38: 217-29

Lee YC, Yellowley CE, Li Z, Donahue HJ, Rannels DE. Expression of functional gap junctions in cultured pulmonary alveolar epithelial cells. Am J Physiol Lung Cell Mol Physiol 1997;272:L1105-14

Li L, Xia Y, Nguyen A, Lai YH, Feng L, Mosmann TR, Lo D. Effects of Th2 cytokines on chemokine expression in the lung: IL-13 potently induces eotaxin expression by airway epithelial cells. J Immunol 1999;162:2477-87

Lilly CM, Tateno H, Oguma T, Israel E, Sonna LA. Effects of allergen challenge on airway epithelial cell gene expression. Am J Respir Crit Care Med 2005;171:579-86

Mochizuki M, Bartels J, Mallet Al, Christophers E, Schroder JM. IL-4 induces eotaxin: a possible mechanism of selective eosinophils recruitment in helminth infection and atopy. $J$ Immunol 1998;160:60-8

Nakamura K, Inai T, Nakamura K, Shibata Y. Distribution of gap junction protein connexin 37 in smooth muscle cells of the rat trachea and pulmonary artery. Arch Histol Cytol 1999;62:27-37

National Institutes of Health, National Heart, Lung, and Blood Institute. Global strategy for asthma management and prevention. WHO/NHLBI Workshop Report. 1995, Publication No. 95-3659

Paul DL. New functions for gap junctions. Curr Opin Cell Biol 1995;7:665-72

Reed KE, Westphale EM, Larson DM, Wang HZ, Veenstra $\mathrm{RD}$, Beyer EC. Molecular cloning and functional expression of human connexin37, an endothelial cell gap junction protein. J Clin Invest 1993;91:997-1004

Romagnani S. Cytokines and chemoattractants in allergic inflammation. Mol Immunol 2002;38:881-5

Saez JC, Berthoud VM, Branes MC, Martinez AD, Beyer EC. Plasma membrane channels formed by connexins: their regulation and functions. Physiol Rev 2003;82:1359-400 
Sohl G, Willecke K. Gap junctions and the connexin protein family. Cardiovasc Res 2004;62:228-32

Striz I, Mio T, Adachi Y, Heires P, Robbins RA, Spurzem JR, Illig MJ, Romberger DJ, Rennard SI. IL-4 induces ICAM-1 expression in human bronchial epithelial cells and potentiates TNF-alpha. Am J Physiol 1999;277:L58-64

Takeda K, Hamelmann E, Joetham A, Shultz LD, Larsen GL, Irvin CG, Gelfand EW. Development of eosinophilic airway inflammation and airway hyperresponsiveness in mast cell-deficient mice. J Exp Med 1997;186:449-54

Teran LM, Mochizuki M, Bartels J, Valencia EL, Nakajima T, Hirai K, Schroder JM. Th1 - and Th2-type cytokines regulate the expression and production of eotaxin and RANTES by human lung fibroblasts. Am J Respir Cell Mol Biol 1999; 20:777-86

Tournoy KG, Kips JC, Schou C, Pauwels RA. Airway eosinophilia is not a requirement for allergen-induced airway hyperresponsiveness. Clin Exp Allergy 2000;30:79-85

van Rijen HV, van Kempen MJ, Postma S, Jongsma HJ. Tumour necrosis factor alpha alters the expression of connexin43, connexin40, and connexin 37 in human umbilical vein endothelial cells. Cytokine 1998;10:258-64

Veenstra RD, Wang HZ, Beyer EC, Ramanan SV, Brink PR. Connexin 37 forms high conductance gap junction channels with subconductance state activity and selective dye and ionic permeabilities. Biophys J 1994;66:1915-28

Wagenaar GT, ter Horst SA, van Gastelen MA, Leijser LM, Mauad T, van der Velden PA, de Heer E, Hiemstra PS,
Poorthuis BJ, Walther FJ. Gene expression profile and histopathology of experimental bronchopulmonary dysplasia induced by prolonged oxidative stress. Free Radic Biol Med 2004;36:782-801

Wardlaw AJ, Symon FS, Walsh GM. Eosinophil adhesion in allergic inflammation. J Allergy Clin Immunol 1994;94:11637

Willecke K, Heynkes R, Dahl E, Stutenkemper R, Hennemann $\mathrm{H}$, Jungbluth $\mathrm{S}$, Suchyna T, Nicholson BJ. Mouse connexin37: cloning and functional expression of a gap junction gene highly expressed in lung. J Cell Biol 1991;114:1049-57

Wong CW, Christen T, Roth I, Chadjichristos CE, Derouette JP, Foglia BF, Chanson M, Goodenough DA, Kwak BR. Connexin 37 protects against atherosclerosis by regulating monocyte adhesion. Nat Med 2006;12:950-4

Yeh HI, Dupont E, Coppen S, Rothery S, Severs NJ. Gap junction localization and connexin expression in cytochemically identified endothelial cells of arterial tissue. J Histochem Cytochem 1997;45:539-50

Yusuf-Makagiansar $\mathrm{H}$, Anderson ME, Yakovleva TV, Murray JS, Siahaan TJ. Inhibition of LFA-1/ICAM-1 and VLA4/VCAM-1 as a therapeutic approach to inflammation and autoimmune diseases. Med Res Rev 2002;22:146-67

Zahler S, Hoffmann A, Gloe T, Pohl U. Gap junctional coupling between neutrophils and endothelial cells: a novel modulator of transendothelial migration. J Leukoc Biol 2003; 73:118-26 